Grafika, Jakarta.

Santoso, Urip, 2010, Pendaftaran dan Peralihan Hak Atas Tanah, Cet ke 3, Kencana Prenada Media Group, Surabaya.

Windia, Wayan P., 2016, Pengantar Hukum Adat Bali, Cetakan Kedua, Kerjasan Swastu Nulus dengan "Bali Shanti" Pusat Pelayanan Konsultasi Adat dan Budaya Bali LPPM Unud dan Puslit Hukum Adat LPPM Unud

\title{
HAK PAKAI ATAS RUMAH HUNIAN WARGA NEGARA ASING DALAM PERKAWINAN CAMPURAN TANPA PERJANJIAN KAWIN
}

\author{
Oleh \\ Eddy Nyoman Winarta* \\ NIM: 1592461015 \\ Mahasiswa Program Magister Kenotariatan Universitas Udayana \\ e-mail : eddywinarta@yahoo.co.id \\ Pembimbing I : Prof. Dr. I Gst, Ngr. Wairocana, SH., MH.* \\ Pembimbing II: Dr. I Made Sarjana, SH., MH.
}

\begin{abstract}
Abstrak
Di Indonesia peraturan mengenai pertanahan diatur dalam Undang-Undang Pokok Agraria (UUPA) No. 5 Tahun 1960, dimana dalam UUPA diatur mengenai larangan atas kepemilikan tanah hak milik bagi orang asing. Sebagai solusi untuk memenuhi keinginan dari orang asing (WNA) untuk memiliki rumah dan tanah di Indonesia, Pemerintah telah mengaturnya dalam Pasal 41 dan Pasal 42 UUPA) dan diatur secara lebih khusus lagi dalam Peraturan Pemerintah Nomor 41 Tahun 1996 yang kemudian diganti dengan Peraturan Pemerintah Nomor 103 Tahun 2015 tentang Pemilikan Rumah Tempat Tinggal Atau Hunian Oleh Orang Asing Yang Berkedudukan di Indonesia. Peraturan Pemerintah ini salah satunya mengatur pemilikan rumah tempat tinggal untuk pasangan perkawinan campuran.

Berdasarkan kondisi tersebut, isu hukum yang diangkat dalam penelitian ini adalah (1) Bagaimanakah pengaturan Hak Pakai atas Rumah Hunian bagi Warga Negara Asing yang melakukan perkawinan campuran?; dan (2) Bagaimanakah akibat hukum dari perkawinan campuran terhadap tanah yang telah dimiliki atas nama Warga Negara Indonesia tanpa membuat perjanjian kawin sebelumnya?

Jenis penelitian yang digunakan merupakan penelitian hukum normatif dengan pendekatan perundang-undangan, pendekatan konsep dan pendekatan kasus. Sumber bahan hukum dalam penelitian ini terdiri dari: primer, sekunder dan tersier. Teknik pengumpulan bahan hukum merupakan teknik studi kepustakaan. Analisis bahan hukum yang berhasil dikumpulkan dalam penelitian ini dilakukan secara deskriptif, interpretatif, evaluatif dan argumentatif analisis.

Hasil penelitian menunjukkan bahwa (1) Pengaturan hak pakai atas tanah bagi Warga Negara Asing yang melakukan perkawinan campuran, jika mereka menikah dengan perjanjian perkawinan maka Warga Negara Indonesia yang melaksanakan perkawinan dengan Orang Asing dapat memiliki hak atas tanah yang sama dengan Warga Negara Indonesia lainnya, hak atas tanah ini bukan merupakan harta bersama yang dibuktikan dengan perjanjian pemisahan harta antara suami dan istri, yang dibuat dengan akta notaris. Sebaliknya, apabila pasangan perkawinan campuran tersebut tidak memiliki perjanjian perkawinan maka harta yang dimiliki selama perkawinan menjadi harta bersama pasangan tersebut, pihak Warga Negara Asing ikut memiliki setengah dari harta tersebut; dan (2) Akibat hukum bila dalam perkawinan campuran telah memiliki tanah atas nama warga negara Indonesia tanpa membuat perjanjian kawin sebelumnya, yang dalam hal ini tidak ada pemisahan harta, maka bagi Warga Negara Indonesia yang sudah memiliki tanah dengan status Hak Milik, dalam masa setahun perkawinannya harus melepaskan Hak Miliknya menjadi tanah negara dan kemudian mengajukan permohonan kembali untuk dijadikan Hak Pakai.
\end{abstract}

\section{Kata Kunci: Kepemilikan Tanah, Orang Asing, Perkawinan Campuran.}

\section{Abstract}

In Indonesia regulations on land use set forth in the Law of Agrarian Tree (UUPA ) No. 5 Year 1960, in which arranged UUPA prohibition on ownership of land ownership for foreigners. As a solution to fulfill the wish of foreigners to have $a$ house and land in Indonesia, the Government had already set in Article 41 and Article 42 of UUPA and more specifically regulated in Government Regulation No. 41 Year 1996 which was then replaced by Government Regulation No. 41 Year 1996 on Ownership of Dwelling or Residential by Foreigners Domiciled in Indonesia. This Government Regulation one of which regulated ownership of dwelling house for couples of intermarriages.

Based on that condition, the legal issues raised in this research are (1) How the regulation of Right of Used of residential by foreigners who carry out inter 
marriages?; and (2) How the legal consequences of intermarriages toward the land has been owned in the name of an Indonesian Citizen without prior making the premarital agreement?

The type of research is a normative legal research with statute approach, conceptual approach and case approach. Sources of legal materials in this research consisted of primary, secondary and tertiary legal materials. The technique of collecting legal material used is literature study techniques. Analysis of legal materials collected in this research performed by a descriptive, interpretative, evaluative and argumentative analysis.

The research result indicated (1) The regulation of Right of Used of residential by foreigners who carry out intermarriages, if they are married with pre-marital agreement then the Indonesian citizens who carry out the marriage by foreigners be able to have the same rights over land by other Indonesian Citizens, this land rights is not a marriages joint properties which is approved by the segregation agreement of properties between husband and wife made by notaries deed. On the contrary, if the intermarriages couple do not have pre-marital agreement then assets owned during the marriage become a marriages joint properties of the couples, the Foreigners Nationals parties have half of that properties; and (2) The legal consequences when in intermarriages has owned the land in the name of citizens of Indonesia without making prior pre-marital agreement, which in this regard there is no segregation of assets, then for Indonesian citizens who own land by Right of Ownership status, in the first year of marriage should release Her/His Rights into state land and then reapply to be a Right of Use.

\section{Keywords: Land Ownership, Foreigners, Intermarriages.}

\section{* Mahasiswa Program Studi Magister Kenotariatan T.A. 2014/2015 ** Pembimbing I \\ *** Pembimbing II}

\section{Pendahuluan}

Perkawinan campuran merupakan fenomena sosial yang semakin berkembang di Kabupaten Badung. Perkawinan campuran berimplikasi terhadap berbagai peristiwa lain yang bersifat ekonomi, sosial maupun hukum. Salah satu implikasi perkawinan campuran adalah Hak Pakai atas rumah hunian Warga Negara Asing (selanjutnya disingkat WNA) yangmelakukan perkawinan campuran dengan Warga Negara Indonesia (selanjutnya disingkat WNI) tanpa membuat perjanjian kawin.

Permasalahan yang muncul bagi pasangan WNA dan WNI yang melangsungkan perkawinan adalah, kebanyakan dari mereka tidak membuat perjanjian kawin sebelum melangsungkan perkawinan. Akibat dari perkawinan yang tidak membuat perjanjian kawin adalah, adanya persatuan harta antara WNA dan WNI tersebut. Akibat hukum dari penyatuan harta dalam perkawinan ini adalah, segala sesuatu dalam perkawinan yang dimiliki oleh WNA adalah juga milik WNI yang terikat perkawinan. Begitu pula sebaliknya, apabila WNI kawin dengan WNA dengan penyatuan harta, maka WNI tidak dapat memiliki Hak Milik atas tanah di Indonesia, karena secara tidak langsung kepemilikan tanah juga menjadi milik pihak WNA. Hal itu dilarang oleh Undang-Undang Nomor 5 Tahun 1960 tentang Peraturan Dasar Pokok-Pokok Agraria (selanjutnya disebut Undang-Undang Pokok Agraria disingkat UUPA) yang menyebutkan seorang WNA dilarang memiliki tanah dengan status Hak Milik di Indonesia. Bagi pasangan WNA-WNI yang tidak dapat memiliki tanah dengan

${ }^{1}$ Aslan Noor, 2006, Konsepsi Hak Milik Atas Tanah Bagi Bangsa Indonesia, CV Mandar Maju, Bandung, hal. 85 . status Hak Milik, masih dapat memiliki tanah dengan status Hak Pakai. Berdasarkan ketentuan Pasal 41 UUPA, definisi dari Hak Pakai adalah sebagai berikut :

"Hak Pakai adalah hak untuk menggunakan dan/atau memungut hasil dari tanah yang dikuasai langsung oleh Negara atau tanah milik orang lain, yang memberi wewenang dan kewajiban yang ditentukan dalam keputusan pemberiannya oleh pejabat yang berwenang memberikannya atau dalam perjanjian dengan pemilik tanahnya, yang bukan perjanjian sewamenyewa atau perjanjian pengolahan tanah, segala sesuatu asal tidak bertentangan dengan jiwa dan ketentuan undang-undang ini”.

Pemberian Hak Pakai kepada WNA selanjutnya diatur dalam Peraturan Pemerintah Nomor 103 Tahun 2015 tentang Pemilikan Rumah Tempat Tinggal atau Hunian oleh Orang Asing yang Berkedudukan di Indonesia (selanjutnya disebut PP Nomor 103 Tahun 2015). Ketentuan Pasal 2 PP Nomor 103 Tahun 2015 ini menyebutkan orang asing dapat memiliki rumah untuk tempat tinggal atau hunian dengan Hak Pakai. Orang asing yang dapat memiliki rumah tempat tinggal atau hunian adalah orang asing pemegang izin tinggal di Indonesia sesuai dengan ketentuan peraturan perundang-undangan.

Meskipun Hak Pakai bagi WNA telah diatur dalam PP Nomor 103 Tahun 2015, namun Hak Pakai masih sering dianggap tidak mampu memberikan kepastian hukum bagi para WNA dan pasangan WNA dan WNI. Mereka merasa Hak Pakai masih banyak memiliki celah-celah yang dapat merugikan mereka. Salah satunya adalah, adanya syarat untuk mengajukan 
permohonan Hak Pakai bagi WNA, yaitu WNA harus memiliki Kartu Izin Tinggal Terbatas (selanjutnya disingkat KITAS) atau Kartu Izin Tinggal Tetap (selanjutnya disingkat KITAP). Permasalahan muncul apabila KITAS tidak dapat diperpanjang sedangkan Hak Pakai sudah akan habis dan harus diperpanjang. Selain itu, mereka juga terus dihadapkan pada ketakutan suatu saat Hak Pakai mereka dapat dicabut sewaktu-waktu oleh pemerintah Indonesia dengan alasan demi kepentingan umum, dengan atau tanpa ganti rugi yang jelas yang tentunya bukan merupakan suatu kepastian hukum yang dikehendaki oleh WNA. Sementara itu, meskipun kepemilikan rumah atau tanah sebagai Hak Pakai oleh WNA sudah diatur dalam PP Nomor 103 Tahun 2015, namun dalam PP Nomor 103 Tahun 2015 sendiri masih terdapat ketidakjelasan pengaturan (norma kabur). Norma kabur ini terdapat dalam ketentuan Pasal 3 PP Nomor 103 Tahun 2015 yang mengatur sebagai berikut :

(1) Warga Negara Indonesia yang melaksanakan perkawinan dengan Orang Asing dapat memiliki hak atas tanah yang sama dengan Warga Negara Indonesia lainnya.

(2) Hak atas tanah sebagaimana dimaksud pada ayat (1), bukan merupakan harta bersama yang dibuktikan dengan perjanjian pemisahan harta antara suami dan istri, yang dibuat dengan akta notaris.

Ketentuan Pasal 3 ayat (1) tersebut di atas tidak menjelaskan WNI lainnya yang tidak melakukan perkawinan campuran dapat memiliki hak atas tanah yang dipersamakan dengan dengan WNI yang melaksanakan perkawinan dengan WNA. Selain itu kekaburan atau ketidakjelasan dari ketentuan Pasal 3 PP Nomor 103 Tahun 2015 tersebut di atas hanya mengatur bagi pasangan WNA dan WNI yang menikah dengan perjanjian pemisahan harta yang dibuat dengan akta Notaris. Pengaturan ini tidak menjelaskan bagaimana dengan pasangan WNA dan WNI yang hanya membuat perjanjian kawin secara di bawah tangan atau bahkan tidak membuat perjanjian kawin sama sekali, mengingat banyak pasangan WNA dan WNI yang membuat perjanjian kawin di bawah tangan atau tidak membuat perjanjian kawin (berlaku seperti halaman 3 ).

Ketentuan Pasal 3 PP Nomor 103 Tahun 2015 yang hanya mengatur perkawinan campuran yang membuat perjanjian pemisahan harta dengan akta Notaris bertentangan pula dengan ketentuan Pasal 29 ayat (1) UU Perkawinan diatur dalam ketentuan Pasal 29 ayat (1) UU Perkawinan bahwa, pada waktu atau sebelum perkawinan dilangsungkan, kedua pihak atas persetujuan bersama dapat mengadakan perjanjian tertulis yang disahkan oleh pegawai pencatat perkawinan. Selain itu dalam bagian ketiga mengenai Perkawinan Campuran yang diatur dalam Pasal 57 sampai dengan Pasal 62 UU Perkawinan dinyatakan bahwa suatu perkawinan campuran tidak mempersyaratkan adanya perjanjian perkawinan yang dibuat dengan akta Notaris. Dengan demikian dapat dikatakan bahwa, terjadi norma konflik antara Pasal 3 PP Nomor 103 Tahun 2015 dengan Pasal 29 dan Pasal 57 sampai dengan Pasal 62 UU Perkawinan.

Berangkat dari adanya norma kabur dalam Pasal 3 PP Nomor 103 Tahun 2015 yang tidak mengatur bagaimana dengan pasangan WNA dan WNI yang hanya membuat perjanjian kawin secara di bawah tangan atau bahkan tidak membuat perjanjian kawin sama sekali dan norma konflik antara Pasal 3 PP Nomor 103 Tahun 2015 yang hanya mengatur perkawinan campuran yang membuat perjanjian pemisahan harta dengan akta Notaris, padahal Pasal 29 ayat (1) dan Pasal 57 sampai Pasal 62 UU Perkawinan menyatakan bahwa suatu perkawinan campuran tidak mempersyaratkan adanya perjanjian perkawinan terlebih-lebih dibuat dengan akta Notaris, maka peneliti tertarik untuk melakukan penelitian dalam bentuk tesis. Menurut peneliti hal tersebut menarik dan penting untuk dibahas agar tidak terjadi kebingungan dalam praktek Notaris sehubungan dengan jaminan kepastian hukum. Adapun judul dari tesis ini adalah "Hak Pakai Atas Rumah Hunian Warga Negara Asing Dalam Perkawinan Campuran Tanpa Perjanjian Kawin".

Berdasarkan latar belakang masalah yang telah diuraikan di atas, maka rumusan masalah dalam penelitian ini dapat dikemukakan dalam research questions adalah (1) Bagaimanakah pengaturan Hak Pakai atas Rumah Hunian bagi Warga Negara Asing yang melakukan perkawinan campuran? dan (2) Bagaimanakah akibat hukum dari perkawinan campuran terhadap tanah yang telah dimiliki atas nama Warga Negara Indonesia tanpa membuat perjanjian kawin sebelumnya?

Adapun tujuan dari penelitian ini adalah (1) Untuk mengetahui dan menganalisis pengaturan Hak Pakai atas Rumah Hunian bagi Warga Negara Asing yang melakukan perkawinan campuran; (2) Untuk mengetahui dan menganalisis akibat hukum dari perkawinan campuran terhadap tanah yang telah dimiliki atas nama Warga Negara Indonesia tanpa membuat perjanjian kawin sebelumnya.

\section{Metode Penelitian}

Berangkat dari adanya norma kabur dalam Pasal 3 PP Nomor 103 Tahun 2015 dan norma konflik antara Pasal 3 PP Nomor 103 Tahun 2015 dengan Pasal 29 ayat (1) dan Pasal 57 sampai Pasal 62 UU Perkawinan, maka dalam penelitian ini digunakan jenis penelitian hukum normatif. Penelitian hukum normatif (normative legal research) merupakan penelitian yang dilakukan dengan cara mengkaji peraturan 
perundang-undangan yang berlaku atau diterapkan terhadap suatu permasalahan hukum tertentu. Penelitian normatif seringkali disebut dengan penelitian doktrinal, yaitu penelitian yang objek kajiannya adalah dokumen peraturan perundang-undangan dan bahan pustaka. ${ }^{3}$ Penelitian hukum normatif juga disebut penelitian yang difokuskan untuk mengkaji penerapan kaidahkaidah atau norma dalam hukum positif. Dalam peneltian normatif hukum dipandang identik dengan norma-norma tertulis, yang dibuat dan diundangkan oleh lembaga atau pejabat yang berwenang dan meninjau hukum sebagai suatu sistem normatif yang otonom, mandiri, tertutup dan terlepas dari kehidupan masyarakat nyata.

\section{TINJAUAN MENGENAI DOKTRIN HAK BANGSA/NEGARA, HAK ATAS TANAH, HAK ATAS TANAH DI INDONESIA MENURUT UUPA, WARGA NEGARA INDONESIA (WNI) DAN WARGA NEGARA ASING (WNA) DAN PERKAWINAN CAMPURAN ANTARA WNI DENGAN WNA}

\subsection{Doktrin Hak Bangsa/Negara}

Menurut Pasal 1 UUPA, "Semua tanah diseluruh wilayah negara Republik Indonesia merupakan karunia Tuhan Yang Maha Esa kepada rakyat Indonesia, yang telah bersatu menjadi Bangsa Indonesia." Dan menurut Pasal 33 ayat (3) UUD NRI 1945, tanah kepunyaan bersama Bangsa Indonesia tersebut penguasaannya ditugaskan kepada Negara Republik. Indonesia, dengan amanat "untuk dipergunakan sebesar-besarnya kemakmuran rakyat Indonesia."

Sehubungan dengan itu, setiap warga negara Indonesia (WNI) diperbolehkan menguasai dan menggunakan tanah kepunyaan bersama tersebut dengan hak apapun yang disediakan oleh Hukum Tanah, kecuali yang secara tegas tidak dimungkinkan oleh peraturan yang bersangkutan, misalnya Hak Pengelolaan. Dengan demikian, negara memiliki kekuasaan sepenuhnya untuk mengatur masalah pertanahan di Indonesia sehingga negara dapat membuat hak-hak yang dapat dilekatkan terhadap suatu tanah.

Hak-hak atas tanah yang diberikan oleh negara kepada individu atau badan hukum merupakan bukti yuridis penguasaan hak atas tanah sehingga pihak lain tidak dapat

${ }^{3}$ Peter Mahmud Marzuki, 2011, Penelitian Hukum, Kencana Prenida Media, Jakarta, hal. 34.

${ }^{4}$ Johny Ibrahim, 2012, Teori dan Metodologi Penelitian Hukum Normatif, Banyumedia, Malang, hal. 295.

${ }^{5}$ Ronny Hanitijo Soemitro, 2008, Metode Penelitian Hukum dan Jurimetri, Alumni, Jakarta, hal 13-14. mengganggu-gugat hak tersebut. Dapat pula dikatakan bahwa subjek hak atas suatu tanah akan mendapatkan perlindungan hukum dan secara tidak langsung meniadakan hak bagi pihak lain yang tidak berkepentingan untuk mengambil alih hak atas tanah tersebut.

\subsection{Hak Atas Tanah di Indonesia Menurut UUPA}

\subsubsection{Hak Milik}

\subsubsection{Pengertian Hak Milik}

Hak milik diatur dalam Pasal 20 sampai dengan Pasal 27 UUPA. Dalam Pasal 20 menyatakan bahwa hak milik adalah hak turun temurun, terkuat dan terpenuh yang dapat dipunyai orang atas tanah dengan mengingat ketentuan dalam Pasal 6. Kata "turun-temurun" dapat diartikan bahwa tanah tersebut dapat diteruskan pada ahli waris, sedangkan untuk kata "terkuat dan terpenuh" itu bermaksud untuk membedakan dengan hak-hak lainnya. Terkuat dapat diartikan sebagai hak memiliki dan atau menguasai atas tanah tersebut dengan jangka waktu yang tak terbatas dengan dilandasi adanya pendaftaran tanah. Terpenuh sama halnya dengan hak yang paling luas dan dapat menjadi induk dari hak lain. Selain itu Hak Milik juga mempunyai fungsi sosial. Hak milik dapat beralih dan dialihkan kepada pihak lain

\subsubsection{Sifat Hak Milik}

Sifat hak milik adalah hak yang "terkuat dan terpenuh" yang dapat dipunyai orang atas tanah. Pemberian sifat ini tidak berarti bahwa hak tersebut merupakan hak "mutlak", tidak terbatas dan tidak dapat diganggu gugat sebagai Hak Eigendom. $^{6}$

\subsubsection{Terjadinya Hak Milik}

Dalam konsep hukum, hubungan antara orang dengan benda merupakan hubungan yang disebut "hak". Makna dari sebutan hak adalah hak kepemegangan atas suatu benda disebut hak milik atas benda atau dikenal sebagai Property Right. $^{7}$

\subsubsection{Peralihan Hak Milik}

Hak milik dapat beralih dan dialihkan kepada pihak lain. Ditinjau dari sudut kepemegangannya, peralihan hak milik atas tanah disebabkan suatu perbuatan hukum yang sengaja dilakukan untuk memindahkan hak milik, dan peristiwa hukum khususnya kematian. Ditinjau dari sudut orang yang memperoleh atau yang menerima, peralihan hak milik terjadi karena dilakukan satu perbuatan hukum tertentu, misalnya jual beli, tukar menukar, hibah. Selain itu perolehan hak milik bisa karena pewarisan.

${ }^{6}$ H. Ali Achmad Chomzah, 2002, Hukum Pertanahan; Pemberian Hak Atas Tanah Negara, Sertipikat dan Permasalahannya, Prestasi Pustaka, Jakarta, hal. 5-6.

${ }^{7}$ Wahid Muchtar, 2008, Memaknai Kepastian Hukum Hak Milik Atas Tanah, Republika, Jakarta, hal. 43. 
pejabat yang ditunjuk berdasarkan usul pemegang Hak Pengelolaan.

\subsubsection{Hapusnya Hak Milik}

Menurut Pasal 27 UUPA, hak milik hapus apabila:

1. Tanahnya jatuh kepada Negara. Hal tersebut terjadi karena pencabutan hak berdasarkan Pasal 18, penyerahan dengan sukarela oleh pemegangnya, ditelantarkan, dan karena ketentuan Pasal 21 ayat (3) dan 26 ayat (2).

2. Tanahnya musnah.

\subsubsection{Hak Pakai}

\subsubsection{Pengertian Hak Pakai}

Fungsi lain dari tanah, yakni fungsi hasil dari suatu tanah. Fungsi hasil dari suatu tanah disebut juga dengan Hak Pakai. Hak Pakai adalah hak untuk menggunakan atau memungut hasil dari tanah yang dikuasai langsung oleh negara, atau sesuai dengan ketentuan dalam Pasal 41 ayat (1) UUPA, yang berbunyi :

"Hak Pakai adalah hak untuk menggunakan dan/atau memungut hasil dari tanah yang dikuasai langsung oleh negara atau tanah milik orang lain, yang memberi wewenang dan kewajiban yang ditentukan dalam keputusan pemberiannya oleh pejabat yang berwenang memberikannya atau dalam perjanjian dengan pemilik tanahnya, yang bukan perjanjian sewamenyewa atau perjanjian pengolahan tanah, segala sesuatu asal tidak bertentangan dengan jiwa dan ketentuan undang-undang ini."

\subsubsection{Subyek dan Obyek Hak Pakai}

Sesuai dengan ketentuan Pasal 42 UUPA yang dapat mempunyai atau subyek Hak Pakai adalah :

1. Warga Negara Indonesia;

2. Orang Asing yang berkedudukan di Indonesia;

3. Badan Hukum yang didirikan menurut hokum Indonesia dan berkedudukan di Indonesia;

4. Badan Hukum Asing yang mempunyai perwakilan di Indonesia.

\subsubsection{Terjadinya Hak Pakai}

Untuk pengaturan mengenai terjadinya Hak Pakai, UUPA tidak mengaturnya. Sehingga pengaturan lebih lanjut ada dalam Pasal 42 ayat (1) dan (2) Peraturan Pemerintah Nomor 40 Tahun 1996, yaitu :

1. Hak Pakai atas Tanah Negara diberikan dengan keputusan pemberian hak oleh Menteri atau pejabat yang ditunjuk;

2. Hak Pakai atas Hak Pengelolaan diberikan dengan keputusan pemberian hak oleh Menteri atau

\section{2.2.4 Hapusnya Hak Pakai}

Berakhirnya jangka waktu sebagaimana ditetapkan dalam keputusan pemberian atau perpanjangannya atau dalam perjanjian pemberiannya; Jangka waktu yang dimaksud adalah sesuai dengan ketentuan Pasal 45 ayat (1), namun demikian selama tanah tersebut dipakai untuk keperluan yang berkaitan dengan kepentingan subyek Hak Pakai18, maka jangka waktunya tidak terbatas. Artinya jangka waktu tersebut akan berakhir apabila sudah tidak digunakan untuk kepentingan subyek Hak Pakai tersebut dan dengan sendirinya Hak Pakai tersebut akan hapus.

\subsubsection{Hak Guna Bangunan \\ 3.2.3.1 Pengertian Hak} Bangunan

Pengaturan hak guna bangunan dalam UUPA adalah dalam Pasal 35 sampai 40. Pasal 35 ayat (1) menyatakan bahwa hak guna bangunan adalah hak untuk mendirikan dan mempunyai bangunanbangunan atas tanah yang bukan miliknya sendiri, dengan jangka waktu paling lama 30 tahun. Selain itu hak guna bangunan juga diatur dalam pasal 19 sampai 38 Peraturan Pemerintah Nomor 40 Tahun 1996. Hak guna bangunan merupakan hak atas tanah yang khusus diperuntukan guna mendirikan bangunan di atasnya, tidak bisa difungsikan untuk kepentingan yang lain.

\subsubsection{Sifat Hak Guna Bangunan}

Sifat-sifat yang dimiliki oleh hak guna bangunan sebagai berikut:

1. Jangka waktunya terbatas, maksimal 30 tahun bisa diperpanjang maksimal 20 tahun. Apabila jangka waktu termasuk perpanjangan sudah habis dan yang bersangkutan masih menghendaki tanah tersebut, maka harus mengajukan permohonan baru.

2. Hak guna bangunan dapat dibebani dengan hak tanggungan, tetapi tidak bisa dibebani dengan hak atas tanah yang lain.

\subsubsection{Subyek Hak Guna Bangunan}

Menurut Pasal 36 ayat (1) UUPA, yang dapat memegang hak guna bangunan ialah:

1. Warga Negara Indonesia

Hanya WNI saja yang dapat memiliki hak guna bangunan. Orang asing tidak dapat mempunyai hak guna bangunan.

2. Badan hukum yang didirikan menurut hukum Indonesia dan berkedudukan di Indonesia.

3. Badan hukum yang mempunyai hak guna bangunan hanya badanbadan yang sama seperti ketentuan tentang 
badan hukum yang menjadi subyek hukum hak milik.

\subsubsection{Hak Guna Usaha}

Negara memegang hak atas tanah sehingga untuk dapat memperoleh hak atas tanah diperlukan penyerahan kepemilikan atas tanah tersebut dari negara kepada subjek hak atas tanah lain, baik perseorangan maupun badan hukum. Penyerahan kepemilikan tersebut dapat dilakukan secara penuh dan dapat juga dilakukan dengan menyerahkan secara sebagian kepemilikan atas tanah tersebut. Maksudnya tanah tersebut diserahkan kepemilikannya kepada subyek atas tanah lain untuk jangka waktu tertentu dan jika jangka waktu tersebut telah tercapai, tanah tersebut harus diserahkan kembali kepada negara. $^{8}$

Hak guna usaha tidak dapat dipunyai oleh warga negara asing. Badan hukum yang bisa mempunyai hak itu hanyalah badan-badan hukum yang bermodal nasional yang progresif, baik asli maupun tidak asli. Bagi badan-badan hukum yang bermodal asing, hak guna usaha hanya dibuka kemungkinannya utuk diberikan jika hal itu diperlukan oleh undang-undang yang mengatur pembangunan nasional berencana. ${ }^{9}$

\subsection{Warga Negara Indonesia (WNI) dan Warga Negara Asing (WNA)}

Warga Negara sesuai dengan definisi Pasal 1 angka 1 UU Kewarganegaraan adalah "Warga suatu negara yang ditetapkan berdasarkan peraturan perundang-undangan." Terkait dengan WNI, maka Pasal 26 ayat (1) UUD NRI 1945 yang kemudian direpetisi di dalam Pasal 2 UU Kewarganegaraan menetapkan bahwa, "Yang menjadi WNI adalah orang-orang bangsa Indonesia asli dan orang-orang bangsa lain yang disahkan dengan undang-undang sebagai Warga Negara." Dengan demikian, maka WNI dapat didefinisikan sebagai orang-orang Bangsa Indonesia asli dan orang-orang bangsa lain yang disahkan dengan undang-undang sebagai WNI.

Pengertian WNI juga terdapat dalam Pasal 4 UU Kewarganegaraan yang secara rinci menyebutkan : Warga Negara Indonesia adalah:

1. Setiap orang yang berdasarkan peraturan perundang- undangan dan/atau berdasarkan perjanjian Pemerintah Republik Indonesia dengan negara lain sebelum UndangUndang ini berlaku sudah menjadi Warga Negara Indonesia;

2. Anak yang lahir dari perkawinan yang sah dari seorang ayah dan ibu Warga Negara Indonesia;

3. Anak yang lahir dari perkawinan yang sah dari seorang ayah Warga Negara Indonesia dan ibu warga negara asing;
4. Anak yang lahir dari perkawinan yang sah dari seorang ayah warga Negara asing dan ibu Warga Negara Indonesia;

5. Anak yang lahir dari perkawinan yang sah dari seorang ibu Warga Negara Indonesia, tetapi ayahnya tidak mempunyai kewarganegaraan atau hukum negara asal ayahnya tidak memberikan kewarganegaraan kepada anak tersebut;

6. Anak yang lahir dalam tenggang waktu 300 (tiga ratus) hari setelah ayahnya meninggal dunia dari perkawinan yang sah dan ayahnya Warga Negara Indonesia;

7. Anak yang lahir di luar perkawinan yang sah dari seorang ibu Warga Negara Indonesia;

8. Anak yang lahir di luar perkawinan yang sah dari seorang ibu warga negara asing yang diakui oleh seorang ayah Warga Negara Indonesia sebagai anaknya dan pengakuan itu dilakukan sebelum anak tersebut berusia 18 (delapan belas) tahun atau belum kawin;

9. Anak yang lahir di wilayah negara Republik Indonesia yang pada waktu lahir tidak jelas status kewarganegaraan ayah dan ibunya;

10. Anak yang baru lahir yang ditemukan di wilayah Negara Republik Indonesia selama ayah dan ibunya tidak diketahui;

11. Anak yang lahir di wilayah negara Republik Indonesia apabila ayah dan ibunya tidak mempunyai kewarganegaraan atau tidak diketahui keberadaannya;

12. Anak yang dilahirkan di luar wilayah negara Republik Indonesia dari seorang ayah dan ibu Warga Negara Indonesia yang karena ketentuan dari negara tempat anak tersebut dilahirkan memberikan kewarganegaraan kepada anak yang bersangkutan;

13. Anak dari seorang ayah atau ibu yang telah dikabulkan permohonan kewarganegaraannya, kemudian ayah atau ibunya meninggal dunia sebelum mengucapkan sumpah atau menyatakan janji setia.

Sementara itu, pengertian Warga Negara Asing (WNA) terdapat dalam Pasal 1 angka 17 UU Nomor 20 Tahun 2009 tentang Gelar, Tanda Jasa, dan Tanda Kehormatan yaitu, "Orang-orang bangsa lain yang disahkan dengan UndangUndang sebagai Warga Negara Asing." Sehubungan dengan pengertian tersebut Pasal 7 UU Kewarganegaraan menyebutkan bahwa, "Setiap orang yang bukan Warga Negara Indonesia diperlakukan sebagai orang asing."

${ }^{8}$ Sembiring Julius, 2004, Pengelolaan Tanah

Kas Desa, Widya Bumi, Yogyakarta, hal.10.

${ }^{9}$ Ibid, hal. 13. 


\subsection{Perkawinan Campuran Antara WNI dengan WNA Menurut Undang-Undang Nomor 1 Tahun 1974 tentang Perkawinan (Undang-Undang Perkawinan)}

Keadaan hukum perkawinan di Indonesia adalah bercorak ragam sifatnya. Bagi setiap golongan penduduk berlaku hukum perkawinan yang berbeda dengan golongan penduduk yang lainnya. Keadaan ini telah menimbulkan persoalan hukum antar golongan di bidang perkawinan, yaitu peraturan hukum perkawinan yang manakah yang akan diberlakukan terhadap suatu perkawinan antara dua orang yang berbeda golongan penduduk dan hukumnya.

Menurut pendapat kebanyakan ahli hukum dan Yurisprudensi yang dimaksudkan diatur selaku "perkawinan Campuran" itu ialah perkawinan antara seorang laki-laki dan seorang perempuan yang masing-masing pada umumnya tunduk/takluk pada hukum yang berlainan.

Dalam menentukan hukum mana yang berlaku bagi orang-orang yang melakukan perkawinan campuran, GHR (Religion op de Gemengde Huwelijken) selanjutnya menyatakan bahwa dalam hal seorang perempuan melakukan perkawinan campuran, maka ia selama pernikahan itu belum putus, tunduk kepada hukum yang berlaku bagi suaminya baik dilapangan hukum publik maupun hukum sipil (Pasal 2 Religion op de Gemengde Huwelijken). Dengan kata lain perempuan yang melakukan perkawinan campuran berubah statusnya menjadi mengikuti status pihak suaminya. Jadi ada penggantian hukum, dari hukumnya sendiri menjadi tunduk kepada hukum sang suami dengan melakukan pemilihan hukum.

Dalam UU Perkawinan, perkawinan campuran tidak dengan sendirinya menentukan isteri takluk pada status kewarganegaraan suami, artinya tidak dengan sendirinya isteri takluk pada hukum yang berlaku bagi suami. Jadi dari ketentuan tersebut, baik laki-laki maupun perempuan memiliki kedudukan yang sama yang mana akan dapat kehilangan kewarganegaraan Indonesia akibat perkawinan campuran tersebut.

Hal ini sesuai dengan apa yang diatur dalam Undang-Undang Kewarganegaraan yang mana laki-laki atau wanita yang melakukan perkawinan campuran akan mengikuti status isteri atau suami apabila Negara dari isteri atau suami menghendaki demikian. Namun apabila tidak, undang-undang memperbolehkan masing-masing pihak mempertahankan kewarganegaraannya

\section{IV.PENGATURAN HAK PAKAI ATAS RUMAH HUNIAN BAGI WARGA NEGARA ASING YANG MELAKUKAN PERKAWINAN CAMPURAN}

4.1 Kepemilikan Hak-Hak Atas Tanah Beserta Bangunan oleh Warga Negara Asing

4.1.1 Penguasaan Hak-Hak Atas Tanah oleh Warga Negara Asing

Hak Milik sebagai hak terkuat dan terpenuh seperti yang telah dipaparkan sebelumnya dilarang untuk dimiliki oleh Warga Negara Asing (WNA). Namun bagi WNA yang ingin "memiliki" rumah atau bangunan dapat melakukan perbuatan hukum yang kemudian disebut dengan Nominee/Trustee Agreement. Konsep ini mekanismenya diatur bahwa pemilik rumah atau bangunan adalah seorang Warga Negara Indonesia (WNI) dengan biaya yang bersumber pada WNA tersebut. Kepemilikan yang dimaksud adalah sebuah kepemilikan yang tidak langsung, yang tercipta dari hubungan hukum antara WNI dan WNA yang dikaitkan di dalam suatu perjanjian yang disebut dengan Nominee/Trustee Agreement, perjanjian tersebut berisikan tentang pernyataan hubungan hukum WNI dengan WNA yang menyatakan bahwa kepemilikan hak atas tanah tersebut pada dasarnya adalah milik dari WNI dan WNA yang bersangkutan yang dapat memerintahkan berbagai tindakan hukum terhadap hak yang "dimiliki" oleh WNA yang dipercaya untuk mengelolanya (trustee). Semisal, memerintahkan tindakan hukum berupa penjaminan atas benda tersebut, menyewakan dan melakukan tindakan hukum lainnya. ${ }^{10}$ Pada umumnya perjanjian Nominee tersebut terdiri atas Perjanjian Induk yang terdiri dari Perjanjian Pemilikan Tanah (Land Agreement) dan Surat Kuasa; Perjanjian Opsi; Perjanjian Sewa-menyewa (Lease Agreement); Kuasa Menjual (Power of Attorney to Sell); Hibah Wasiat; dan Surat Pernyataan Ahli Waris. ${ }^{11}$

Terhadap Hak Pakai seperti yang telah dipaparkan sebelumnya oleh penulis bagi perorangan Warga Negara Asing jika ingin memiliki tanah dan bangunan di atasnya, maka kelembagaan Hak Pakai ini yang memberikan peluang kepemilikan dalam jangka waktu tertentu. Hak Pakai bagi warga negara asing

${ }^{10}$ Arie S, Hutagalung, 2007, "Kemungkinan Pemilikan Satuan Rumah Susun oleh OrangOrang Asing di Indonesia”, Seminar Liberalisasi Hukum Tanah Indonesia, Balai Sidang Djokosoetono Fakultas Hukum Universitas Indonesia, Depok.

${ }^{11}$ Maria S.W. Sumardjono, 2010, Kebijakan Pertanahan: Antara Regulasi dan Implementasi, Kompas, Jakarta, hal. 14. 
didasarkan pada Peraturan Pemerintah Nomor 41 Tahun 1996 tentang Pemilikan Rumah Tempat Tinggal atau Hunian oleh Orang Asing yang berkedudukan di Indonesia yang kemudian diganti dengan Peraturan Pemerintah Nomor 103 Tahun 2015 tentang Pemilikan Rumah Tempat Tinggal atau Hunian oleh Orang Asing yang Berkedudukan di Indonesia. Pasal 2 ayat (1) dan (2) Peraturan Pemerintah Nomor 103 Tahun 2015 ini mengatur bahwa orang Asing dapat memiliki rumah untuk tempat tinggal atau hunian dengan Hak Pakai. Orang Asing yang dapat memiliki rumah tempat tinggal atau hunian adalah Orang Asing pemegang izin tinggal di Indonesia sesuai dengan ketentuan peraturan perundang-undangan. Rumah tunggal yang diberikan kepada orang asing di atas tanah hak pakai diberikan untuk jangka waktu 30 (tiga puluh) tahun, dapat diperpanjang untuk jangka waktu 20 (dua puluh) tahun dan dapat diperbaharui untuk jangka waktu 30 (tiga puluh) tahun.

Adapun orang asing yang dapat memiliki Hak Pakai di Indonesia ialah orang asing yang kehadirannya memberikan manfaat terhadap pembangunan Indonesia. Apabila orang asing tersebut tidak lagi berkedudukan di Indonesia, dalam jangka waktu 1 (satu) tahun wajib melepaskan atau mengalihkan hak atas rumah dan tanahnya kepada orang lain yang memenuhi syarat. Dan apabila rumah tersebut dalam jangka waktu 1 (satu) tahun belum dialihkan atau dilepaskan haknya, dan jika rumah tersebut didirikan di atas tanah Hak Pakai Negara, maka rumah tersebut akan dilelang untuk kemudian dijual, dan jika rumah tersebut didirikan di atas tanah berdasarkan perjanjian, maka rumah tersebut menjadi milik pemegang hak atas tanah yang bersangkutan.

\subsubsection{Kepemilikan Rumah Hunian oleh Warga Negara Asing}

Sebagai tindak lanjut ketentuan dari pengaturan yang terdapat pada UUPA khususnya tentang kepemilikan tanah bagi warga negara asing atau badan hukum asing di Indonesia, berkaitan pula dengan pengaturan kepemilikan rumah susun bagi warga negara asing sebagaimana yang tidak jelas diatur dalam Undang-Undang Rumah Susun, serta beberapa ketentuan mengenai perumahan yang diatur dalam Undang-Undang Perumahan dan Permukiman, dalam upaya memberikan hak kepada warga negara asing yang berada di Indonesia serta dalam rangka memberikan kepastian hukum mengenai pemilikan rumah tempat tinggal atau hunian untuk orang asing, diterbitkan peraturan pemerintah, peraturan menteri agraria seperti tersebut di bawah ini.

Peraturan Pemerintah Nomor 41 Tahun 1996 tentang Pemilikan Rumah Tempat Tinggal atau Hunian oleh Orang Asing yang berkedudukan di Indonesia yang kemudian diganti dengan Peraturan Pemerintah Nomor 103 Tahun 2015 tentang Pemilikan Rumah Tempat Tinggal atau Hunian oleh Orang Asing yang Berkedudukan di Indonesia. Secara garis besar Peraturan Pemerintah Nomor 103 Tahun 2015 memuat ketentuan sebagai berikut: ${ }^{12}$

1. Pada prinsipnya, orang asing yang berkedudukan di Indonesia diperkenankan memiliki 1 (satu) rumah tempat tinggal, bisa berupa rumah yang berdiri sendiri, atau Satuan Rumah Susun yang dibangun di atas tanah Hak Pakai.

2. Rumah dan atau Rumah Susun yang berdiri sendiri dapat dibangun di atas tanah Hak Pakai atas tanah Negara; atau diatas tanah Hak Pakai yang berasal dari tanah Hak Milik yang diberikan oleh pemegang Hak Milik dengan Akta Pejabat Pembuat Akta Tanah (PPAT).

3. Perjanjian pemberian Hak Pakai di atas tanah Hak Milik adalah wajib dicatat dalam Buku Tanah dan Sertipikat Hak Milik yang bersangkutan.

4. Jangka waktu Hak Pakai tersebut diberikan untuk jangka waktu 30 (tiga puluh) tahun, dapat diperpanjang untuk jangka waktu 20 (dua puluh) tahun. Hak Pakai tersebut dapat diperbaharui untuk jangka waktu 30 (tiga puluh) tahun.

5. Apabila orang asing yang memiliki rumah yang dibangun di atas tanah Hak Pakai atas tanah negara, atau yang berdasarkan perjanjian dengan pemegang hak Milik tidak berkedudukan lagi di Indonesia, maka dalam jangka waktu 1 (satu) tahun wajib melepaskan atau mengalihkan hak atas rumah/bangunan dan tanahnya kepada pihak lain yang memenuhi syarat.

6. Apabila dalam jangka waktu tersebut hak atas tanah belum dilepaskan atau dialihkan kepada pihak lain yang memenuhi syarat, maka terhadap rumah/bangunan yang dibangun di atas tanah Hak Pakai atas Tanah Negara, rumah/bangunan beserta tanah yang dikuasai Warga Negara Asing itu akan dilelang. Dan terhadap rumah tersebut yang dibangun di atas tanah Hak Pakai atas tanah Hak Milik, maka rumah/bangunan tersebut menjadi milik pemegang hak Milik.

Kepemilikan tersebut tetap dibatasi pada 1 (satu) buah rumah. Tujuan pembatasan ini adalah untuk mejaga kesempatan kepemilikan tersebut tidak menyimpang dari tujuannya, yaitu sekedar memberikan dukungan yang wajar bagi penyelenggaraan usaha orang asing tersebut di Indonesia. Jadi Hak Milik Sarusun yang di bangun di atas Hak Milik dan Hak Guna

${ }^{12}$ Ibid., hal. 216. 
Bangunan tidak dimungkinkan dimiliki oleh Warga Negara Asing (WNA). Akan tetapi WNA hanya dimungkinkan memiliki Hak Milik sarusun yang dibangun di atas Hak Pakai di atas Tanah Negara.

Bahwa orang asing yang telah memiliki rumah di Indonesia tidak lagi memenuhi syarat berkedudukan di Indonesia, maka dalam jangka waktu paling lama 1 (satu) tahun wajib mengalihkan haknya kepada pihak lain yang memenuhi syarat.

Terhadap bangunan yang bukan/non hunian, persyaratan kepemilikan bagi orang asing dan badan hukum asing berupa bangunan yang berdiri sendiri maupun Rumah Susun yang penggunaannya adalah untuk perkantoran maupun tempat usaha/bangunan komersial. Hak atas tanah beserta bangunan yang dimiliki oleh Orang Asing/WNA dan badan hukum asing juga dapat dijadikan jaminan utang dengan dibebani Hak Tanggungan, sesuai dengan ketentuan yang diatur dalam Undang-Undang No. 4 tahun 1996 tentang Hak Tanggungan.

\subsection{Pemilikan Tanah oleh Orang Asing Setelah Berlakunya Peraturan Pemerintah Nomor 103 Tahun 2015 tentang Rumah Tempat Tinggal atau Hunian oleh Orang Asing yang Berkedudukan di \\ Indonesia}

Pada umumnya pemberian rumah tempat tinggal kepada orang asing tersebut digunakan sebagai sarana untuk memperlancar investasi maupun usaha, yang diharapkan mampu memberikan dampak positif terhadap perekonomian nasional. Saat ini kebutuhan orang asing akan perumahan tersebut diakomodir oleh PP Hunian Orang Asing yang baru diterbitkan pada tanggal 28 Desember 2015 yang merupakan pembaruan dari PP serupa yang sebelumnya telah terbit pada 17 Juni 1996. Dalam PP Hunian Orang Asing tersebut terdapat beberapa pembaruan, khususnya definisi orang asing yang berkedudukan di Indonesia sebagai subjek yang disebutkan dalam PP Hunian Orang Asing.

Pasal 1 PP Hunian Orang Asing mendefinisikan orang asing yang berkedudukan di Indonesia sebagai orang yang bukan WNI yang keberadaanya memberikan manfaat, melakukan usaha, bekerja, atau berinvestasi di Indonesia. Definisi tersebut mengalami perluasan dari definisi sebelumnya yang diatur dalam PP Hunian Orang Asing 1996, yang mengartikan orang asing yang berkedudukan di Indonesia adalah orang asing yang kehadirannya di Indonesia memberikan manfaat bagi pembangunan nasional. Definisi tersebut kemudian diperjelas dalam Peraturan Menteri Agraria/Kepala BPN No. 7 Tahun 1996 tentang Persyaratan Pemilikan Rumah Tempat Tinggal atau Hunian oleh Orang Asing yang menegaskan bahwa definisi tersebut merujuk kepada orang asing yang memiliki dan memelihara kepentingan ekonomi di Indonesia dengan melaksanakan investasi untuk memiliki rumah tempat tinggal atau hunian di Indonesia. Sebelumnya, orang asing yang berkedudukan di Indonesia juga dimuat dalam Pasal PP No. 40/1996 sebagai subjek dari Hak Pakai. Dalam penjelasan Pasal 39 PP No. 40/1996 tersebut dinyatakan bahwa orang asing yang berkedudukan di Indonesia adalah orang asing yang kehadirannya di Indonesia memberikan manfaat bagi pembangunan nasional. Ketiga definisi tersebut mempunyai kesamaan yang tidak berubah dalam menentukan orang asing yang berkedudukan di Indonesia, yaitu orang bukan WNI yang berkontribusi terhadap pembangunan ekonomi nasional.

Definisi yang terdapat dalam PP Hunian Orang Asing dapat dilihat bahwa ada dua kriteria yang digunakan untuk menentukan orang asing yang berkedudukan di Indonesia, yaitu bukan WNI dan memberikan manfaat, melakukan usaha, bekerja atau berinvestasi di Indonesia. Walaupun demikian, definisi tersebut terlampau luas. Hal tersebut dikarenakan dalam mendefinisikan orang asing yang berkedudukan di Indonesia, digunakannya kata "atau" yang menunjukkan sifat alternatif dalam memenuhi kriteria tersebut.

Dalam menentukan apakah seseorang merupakan orang asing yang berkedudukan di Indonesia terdiri atas dua kriteria, yaitu:

a. Bukan Warga Negara Indonesia yang memiliki Izin Tinggal di Indonesia; dan

b. Memberikan Manfaat bagi Indonesia; atau

c. Mempunyai atau menjalankan usaha di Indonesia; atau

d. Bekerja di Indonesia; atau

e. Berinvestasi di Indonesia.

Dalam PP Hunian Orang Asing, orang asing yang berkedudukan di Indonesia diperbolehkan memiliki rumah tunggal unit baru dengan Hak Pakai di atas tanah Hak Pakai atas tanah negara, Hak Pengelolaan atas tanah negara atau Hak Pakai di atas Hak Milik yang dikuasai berdasarkan perjanjian. Selain rumah tunggal, orang asing yang berkedudukan di Indonesia juga dapat memiliki Sarusun dengan Hak Milik pada dibidang tanah Hak Pakai atas tanah negara atau Hak Pengelolaan. Hak Pakai atas rumah tunggal tersebut diberikan untuk jangka waktu 30 tahun yang dapat diperpanjang untuk jangka waktu 20 tahun serta dapat diperbarui untuk jangka waktu 30 tahun. Dengan demikian, Hak Pakai atas rumah tunggal tersebut paling lama dimiliki selama 80 tahun.

Adanya anggapan bahwa PP Hunian Orang Asing merupakan lex specialis dari PP No. 40 Tahun 1996 yang merupakan lex generalis. Dalam asas lex specialis derogat legi generalis tersebut menyatakan bahwa hukum yang lebih khusus mengenyampingkan hukum yang lebih umum. Akan tetapi asas tersebut tidak dapat dipakai sembarangan. Dalam menggunakan asas tersebut, sebelumnya terdapat dua kriteria yang harus dipenuhi yaitu (1) merupakan produk 
hukum yang setara; dan (2) produk hukum tersebut berada dalam satu rezim hukum yang sama. Kedua regulasi tersebut berbentuk PP yang sederajat, akan tetapi keduanya berada dalam rezim hukum yang berbeda. PP No. 40/1996 tunduk kepada hukum tanah, sedangkan PP Hunian Orang Asing tunduk kepada hukum perhutangan yang mengatur penguasaa hak atas benda bukan tanah. Van Dijk mengatakan bahwa hukum perhutangan bukan dimaksud sebagai hukum hutang piutang, tapi sebagai hukum yang mengatur tentang penguasaan atas benda bukan tanah serta peralihan dan hukum jasa-jasa. ${ }^{13} \mathrm{Hal}$ ini adalah konsekuensi dari dianutnya Asas Pemisahan Horizontal yang bersumber dari Hukum Adat dalam hukum tanah nasional. Maka dari itu penggunaan asas lex specialis derogat legi generalis kurang tepat.

PP Hunian Orang Asing menentukan bahwa pemilikan rumah tunggal sebagai tempat tinggal orang asing yang berkedudukan di Indonesia berdasarkan atas Hak Pakai terhadap rumah tunggal diatas Hak Pakai di atas tanah negara atau Hak Pengelolaan atau Hak Pakai di atas Hak Milik yang dikuasai berdasarkan perjanjian pemberian. Kedudukan orang asing yang berkedudukan di Indonesia sebagai subjek Hak Pakai dalam PP Hunian Orang Asing tersebut sudah sesuai dengan orang asing yang berkedudukan di Indonesia yang dimaksud dalam PP No. 40 Tahun 1996, yaitu orang asing yang kehadirannya di Indonesia memberikan manfaat bagi pembangunan nasional, seperti yang dijelaskan sebelumnya.

Selain dapat memiliki rumah tunggal dengan status Hak Pakai, orang asing yang berkedudukan di Indonesia juga memiliki pilihan untuk memiliki Sarusun dengan status HMSRS yang bersifat perseorangan yang terpisah dengan hak bersama atas bagian bersama, benda bersama, dan tanah bersama. Adanya HMSRS bukan dalam artian pemilik dapat memiliki Sarusun tersebut selamalamanya, tetapi bergantung kepada status hak atas tanahnya. PP Hunian Orang Asing menetapkan Sarusun yang dapat dimiliki oleh orang asing yang berkedudukan di Indonesia dibangun di atas tanah Hak Pakai atas tanah negara atau tanah pengelolaan dengan jangka waktu paling lama 25 tahun dan dapat diperpanjang untuk jangka waktu paling lama 20 tahun dan dipembaruan paling lama selama 25 tahun. Ketentuan ini juga berarti orang asing yang memiliki HMSRS bukan otomatis memiliki tanah dengan status Hak Milik. Hal ini disebabkan karena Asas Pemisahan Horizontal yang dianut oleh hukum tanah

${ }^{13}$ Van Dijk, 2006, Pengantar Hukum Adat Indonesia, diterjemahkan oleh A. Soehardi, Mandar Maju, Bandung, hal. 87 dalam Eman Ramelan, 2008, "Asas Pemisahan Horizontal dalam Hukum Tanah Nasional," Pidato Pengukuhan, Guru Besar Ilmu Hukum Agraria Universitas Airlangga. nasional dan karakteristik dari tanah Rusun yang berstatus tanah bersama.

\subsection{Keberadaan Hak Pakai Bagi Warga Negara Asing yang Melakukan Campuran \\ Perkawinan \\ Perkawinan campuran bukanlah hal baru} bagi masyarakat Indonesia. Sebagai negara yang menjadi poros perdagangan dunia di masa lalu, membuat masyarakat Indonesia berinteraksi orang dari negara lain. Hal tersebut semakin tinggi intensitasnya manakala globalisasi dan modernisasi makin mempermudah setiap orang untuk berbagai keperluannya, bahkan untuk mengenal orang dari negara lain ataupun berpindah dari satu negara ke negara lain.

Salah satu persoalan yang timbul karena adanya harta bersama terjadi ketika objek harta bersama tersebut merupakan tanah yang dimiliki oleh WNI, baik posisinya sebagai suami ataupun istri. Hal tersebut dikarenakan tanah tidak dapat dimiliki oleh orang asing, baik statusnya berkedudukan di Indonesia ataupun tidak. Tidak dapat dimiliki dalam hal ini merupakan hak penguasaan atas tanah yang di dasari oleh Hak Milik. Ketentuan ini merupakan konsekuensi dengan adanya Hak Bangsa yang merupakan hak penguasaan tanah tertinggi yang menempatkan seluruh bangsa Indonesia sebagai pemilikinya. Ketentuan terebut juga diperkuat dengan Pasal 9 ayat (1) UUPA yang mengatur hanya WNI dapat mempunyai hubungan yang sepenuhnya dengan bumi, air, ruang angkasa dan seluruh kekayaan alam yang ada di Indonesia. Ketentuan tersebut selanjutnya dipertegas oleh Pasal 21 ayat (1) UUPA yang menegaskan hanya WNI yang dapat mempunyai Hak Milik.

Biarpun UU Perkawinan telah membagi harta perkawinan, ketentuan dalam Pasal 21 ayat (3) UUPA tetap berlaku jika tanah dijadikan sebagai harta bersama. Akan tetapi, jika melihat rumusan Pasal 21 ayat (3) UUPA, dapat ditafsirkan bahwa jika harta tersebut tidak bercampur maka WNI yang melakukan perkawinan campuran dapat memiliki Hak Milik sama seperti ketika ia belum melakukan perkawinan campuran. Mengenai pemisahan harta perkawinan dapat dilakukan dengan menggunakan perjanjian perkawinan.

Pasal 29 UU Perkawinan memuat ketentuan tentang perjanjian perkawinan yang dibuat secara tertulis sebelum atau pada waktu perkawinan dilangsungkan yang berlaku sejak perkawinan dilangsungkan serta tidak dapat diubah kecuali bila kedua belah pihak ada persetujuan untuk mengubah dan tidak merugikan pihak ketiga. Adanya perjanjian perkawinan yang di dalamnya memuat pemisahan harta selama perkawinan dapat digunakan juga dalam perkawinan campuran. Biarpun demikian, rumusan Pasal 29 ayat (1) UU Perkawinan yang menetapkan bahwa perjanjian perkawinan dibuat pada waktu atau sebelum perkawinan dilangsungkan telah 
menutup kemungkinan diadakannya perjanjian perkawinan ketika perkawinan itu sudah berlangsung.

Terkait pemilikan tanah oleh WNI yang melakukan perkawinan campuran, Pasal 3 ayat (1) PP Hunian Orang Asing menetapkan bahwa WNI pelaku perkawinan campuran diberikan hak atas tanah yang sama dengan WNI lainnya. Ketentuan ini sekilas bertentangan dengan Pasal 21 ayat (3) UUPA, akan tetapi seperti yang uraikan pada pembahasan sebelumnya bahwa Hak Milik atas tanah merupakan hak bagi semua WNI, tidak memandang apakah ia laki-laki atau wanita, lajang ataupun kawin, kawin dengan sesama WNI ataupun dengan orang asing. Pasal 3 ayat (2) PP Hunian Orang Asing menetapkan bahwa hak atas tanah yang dimiliki oleh WNI pelaku perkawinan campuran bukan merupakan harta bersama yang dibuktikan dengan perjanjian pemisahan harta, dalam hal ini adalah perjanjian perkawinan. Biarpun demikian, hal ini terkendala dengan Pasal 29 UU Perkawinan yang menentukan perjanjian perkawinan dibuat sebelum atau pada saat perkawinan berlangsung seperti yang telah diurai sebelumnya

\section{AKIBAT HUKUM DARI PERKAWINAN CAMPURAN TERHADAP TANAH YANG TELAH DIMILIKI ATAS NAMA WARGA NEGARA INDONESIA TANPA MEMBUAT PERJANJIAN KA WIN SEBELUMNYA \\ 5.1 Kedudukan Suami Isteri dalam Perkawinan Campuran \\ Mengenai akibat hukum perkawinan, dalam} Hukum Perdata Internasional (HPI) berkembang beberapa asas yang menyatakan akibat hukum perkawinan tunduk pada $:^{14}$

1. Sistem hukum tempat perkawinan diresmikan/dilangsungkan (lex loci celebrationis).

2. Sistem hukum dari tempat suamiisteri bersama-sama menjadi warga negara setelah perkawinan (join nationality)

3. Sistem hukum dari tempat suamiisteri berkediaman tetap bersamasama setelah perkawinan (join residence) atau tempat suami berdomisili tetap setelah perkawinan.

Berdasarkan asas HPI di atas, maka menyangkut kedudukan suami isteri dalam perkawinan campuran sebagai salah satu akibat hukum perkawinan tunduk pada asas lex loci celebrationis, dikarenakan perkawinan campuran merupakan perkawinan antara WNI dengan WNA yang dilangsungkan di Indonesia. Maka dari itu, kedudukan suami isteri dalam perkawinan campuran harus merujuk kepada hukum perkawinan di Indonesia, yakni UU Perkawinan. Dan sebagaimana tedapat dalam Pasal 59 ayat (2):

Perkawinan campuran yang dilangsungkan di Indonesia dilakukan menurut Undang- undang perkawinan ini.

Yang dimaksud kedudukan suami-isteri adalah dimana di dalamnya terdapat pengaturan hak dan kewajiban suami-isteri. Hak dan kewajiban suami isteri diatur secara tuntas dalam UU Perkawinan dalam satu bab yaitu Bab VI yang terdiri dari Pasal 30 sampai dengan Pasal $34^{15}$

\subsection{Status Hukum Hak Kepemilikan Atas Tanah bagi Orang Asing yang Melakukan Perkawinan Campuran di Indonesia}

Kepemilikan atas tanah bagi orang asing yang melakukan perkawinan campuran di Indonesia, telah menjadi sorotan oleh sebagian besar warga masyarakat. Banyak pertanyaan bermunculan bagaimanakah status kepemilikan hak atas tanah atau properti di Indonesia apabila seorang WNI menikah dengan seorang WNA. Dalam kasus ini, sebelum menjawab pertanyaan tersebut, terlebih dahulu dipertanyakan kembali kepada pasangan berbeda kewarganegaraan tersebut, apakah mereka menikah dengan Perjanjian Kawin (Pre-Marital Agreement) atau tanpa perjanjian tersebut? Apabila mereka memakai Perjanjian Kawin maka tidak ada percampuran harta sehingga harta yang dimiliki oleh para pihak menjadi milik masing-masing.

Sebaliknya, apabila pasangan perkawinan campuran tersebut tidak memiliki Perjanjian Kawin maka harta yang dimiliki selama perkawinan menjadi harta bersama pasangan tersebut, dengan kata lain pihak WNA ikut memiliki setengah dari tanah tersebut. Sehingga WNI yang menikah dengan WNA (tanpa Perjanjian Kawin) dipaksa untuk tunduk pada ketentuan peraturan yang diperuntukkan bagi orang asing.

Berdasarkan Pasal 42 dan 45 UUPA dan diatur lebih lanjut dengan Peraturan Pemerintah Nomor 40 Tahun 1996 tentang Hak Guna Bangunan (HGB), Hak Guna Usaha (HGU) dan Hak Pakai (HP) atas tanah, WNA dapat memiliki Hak Pakai dan Hak Sewa saja. Sehingga WNI yang menikah dengan WNA tanpa perjanjian kawin otomatis digolongkan sebagai subyek hukum yang hanya berhak untuk mendapatkan Hak Pakai atau Hak Sewa.

Berdasarkan Perjanjian Kawin ini maka tidak terdapat percampuran harta sehingga harta yang dimiliki oleh para pihak menjadi milik masing-masing jadi tidak menjadi masalah apabila WNI membeli dan memiliki hak atas tanah dan bangunan di Indonesia. WNI yang sudah terlanjur menikah dengan WNA tanpa
${ }^{14}$ Ridwan Khairandy, 1999, Pengantar Hukum Perdata Internasional Indonesia, Gama Media, Yogyakarta, hal. 137.

\section{${ }^{15}$ Amir Syarifuddin, 2009, Hukum} Perkawinan Islam di Indonesia, Kencana, Jakarta, hal. 164-165. 
perjanjian kawin, sebaiknya tanah yang dimiliki di Indonesia segera dipindahtangankan dengan cara dijual atau dihibahkan kepada orang tua, anak, saudara kandung atau kerabat sebelum diketahui oleh pemerintah yang dapat menyebabkan hak atas tanah tersebut hapus dan jatuh kepada Negara tanpa ganti rugi sesuai dengan peraturan Pasal 21 (ayat (3)) UUPA di atas.

\subsection{Harta Benda Perkawinan dalam Harta Bersama Akibat Perkawinan Campuran}

Pengaturan mengenai harta benda dalam perkawinan campuran sebagai salah satu akibat hukum perkawinan, sebagaimana telah diuraikan di atas dalam Hukum Perdata Internasional (HPI) tunduk pada asas lex loci celebrationis, dikarenakan perkawinan campuran merupakan perkawinan antara WNI dengan WNA yang dilangsungkan di Indonesia. Maka dari itu, pengaturan harta benda perkawinan dalam perkawinan campuran merujuk pada hukum perkawinan di Indonesia, yakni UU Perkawinan. Dan sebagaimana diatur dalam Pasal 59 ayat (2).

Harta kekayaan yang dihasilkan setelah terjadinya perkawinan disebut dengan harta gonogini atau "harta bersama", yaitu harta yang diperoleh atas usaha bersama oleh suami isteri terhitung sejak dilangsungkannya perkawinan. Itulah yang dimaksud dengan harta bersama dalam hukum perkawinan di Indonesia atau bisa disebut juga dengan harta serikat".

Abdul Manan berpendapat di dalam bukunya, bahwa : "harta bersama adalah semua harta yang diperoleh selama perkawinan berlangsung, tanpa mempersoalkan siapa di antara suami isteri yang mencarinya dan juga tanpa mempersoalkan atas nama siapa harta kekayaan itu terdaftar". ${ }^{16}$

Menurut Mohd. Idris Ramulyo yang mengutip perkataan Sayuti Thalib dalam bukunya Hukum Kekeluargaan Indonesia, harta benda dalam perkawinan disebut juga dengan harta pencaharian. Yang dimaksud harta pencaharian adalah harta yang diperoleh sesudah mereka berada dalam hubungan perkawinan berlangsung, baik atas usaha mereka berdua atau salah seorang dari mereka. ${ }^{17}$

Subekti berpendapat di dalam bukunya, bahwa : "sejak dimulainya perkawinan, terjadi suatu percampuran antara kekayaan suami dan kekayaan isteri, jikalau tidak diadakan perjanjian

${ }^{16}$ Abdul Manan, 2006, Aneka Masalah Hukum Perdata Islam di Indonesia, Kencana Prenada Media Group, Jakarta, hal. 108.

${ }^{17}$ Mohd. Idris Ramulyo, 2006, Hukum Perkawinan, Hukum Kewarisan, Hukum Acara Peradilan Agama, dan zakat menurut hukum Islam, Sinar Grafika, Jakarta, hal. 29. perkawinan. ${ }^{18}$ Percampuran kekayaan adalah mengenai seluruh aktiva dan pasiva, baik yang dibawa oleh masing-masing pihak ke dalam perkawinan, maupun yang akan diperoleh di kemudian hari selama perkawinan". ${ }^{19}$ Menurut KUHPerdata (Pasal 119), prinsip harta benda perkawinan adalah harta persatuan bulat antara suami isteri. $^{20}$

Berdasarkan uraian di atas, dapat disimpulkan bahwa definisi harta bersama yang terdapat dalam Pasal 35 (ayat 1) UU Perkawinan dan Pasal 85 KHI (Inpres No. 1 Tahun 1991) yang mana dikatakan, bahwa harta bersama antara suami isteri adalah harta yang diperoleh selama perkawinan berlangsung adalah kaidah atau definisi yang dipegangi sekarang ini untuk menentukan pengertian hukum harta bersama. Klausula tersebut di atas tidak lagi menjadi syarat utama dalam terbentuknya harta bersama. ${ }^{21}$

\subsection{Akibat Hukum Tanah yang Telah Dimiliki Atas Nama Warga Negara Indonesia dalam Perkawinan Campuran tanpa Membuat Perjanjian Kawin Sebelumnya}

Kepemilikan Harta Benda Perkawinan bagi Suami WNI dalam Harta Bersama Akibat Perkawinan Campuran dapat ditegaskan sebagai berikut: Kepemilikan tanah dan rumah, Pada dasarnya kepemilikan itu berada di tangan suami. Kepemilikan tanah atas nama suami WNI dalam harta bersama akibat perkawinan campuran tetap terjadi. Hal tersebut dikarenakan hukum di Indonesia menyatakan, bahwa perempuan yang telah kawin pada umumnya tidak diperbolehkan bertindak sendiri dalam hukum, tetapi harus dibantu oleh suaminya. Ia termasuk dalam golongan orang yang oleh hukum dianggap kurang cakap untuk bertindak sendiri. ${ }^{22}$ Akan tetapi, hal tersebut tidak berlaku sebaliknya terhadap suami. Suami diperbolehkan bertindak sendiri dalam hukum tanpa harus dibantu oleh isterinya.

Dalam harta bersama akibat perkawinan campuran, status kepemilikan atas tanah dalam perkawinan tersebut semua atas nama suami WNI. Suami WNI dalam perkawinan campuran tidak mengetahui adanya aturan yang mengatur tentang kepemilikan dalam percampuran harta akibat perkawinan campuran.

Sebagaimana telah dijelaskan sebelumnya, bahwa perempuan/isteri WNI turut terkena imbas aturan tersebut di atas. Lain halnya dengan lakilaki/suami WNI, mereka tidak turut terkena imbas aturan tersebut. Yang mana berdasarkan

${ }^{18}$ Subekti, 1995, Pokok-pokok Hukum Perdata, Cetakan XXVII, Internusa, Jakarta, hal.31.

${ }^{19}$ Ibid, hal. 32.

${ }^{20}$ Simanjuntak, 2009, Pokok-Pokok Hukum

Perdata Indonesia, Djambatan, Jakarta, hal. 49.

${ }^{21}$ Ibid, hal. 300-302.

${ }^{22}$ Subekti, op.cit., hal. 20. 
aturan di atas tidak hanya WNA saja yang harus melepaskan hak miliknya dalam percampuran harta akibat perkawinan campuran. Akan tetapi, pasangan WNI-nya (isteri/suami) juga harus melepaskan hak miliknya.

Tanpa adanya perjanjian perkawinan (terjadi percampuran harta) ternyata, jika itu suami WNI walaupun dalam perkawinan campuran tetap bisa memiliki rumah di Indonesia dengan sertifikat hak milik. Ketika melakukan pembelian rumah tidak dipertanyakan warga negara pasangannya, apakah warga negara Indonesia atau asing. Dikarenakan yang melakukan transaksi tersebut adalah suami WNI, yang mana kedudukan lakilaki atau suami itu kuat berdasarkan hukum Indonesia yang bersifat patriarkat (kedudukan lakilaki lebih kuat dari pada perempuan).

Harta Benda sebelum perkawinan campuran, tentunya merujuk sepenuhnya kepada ketentuan hukum nasional Indonesia yang berlaku mengenai harta gono gini. Sedangkan harta benda sesudah perkawinan campuran merujuk kepada hukum nasional Indonesia serta hukum asing yang terlibat dalam perkawinan tersebut.

Harta Kekayaan Perkawinan menurut KUHPerdata adalah berdasarkan ketentuan Pasal 119 KUHPerdata, apabila calon suami isteri sebelum perkawinan dilangsungkan tidak dibuat perjanjian kawin, dalam mana persatuan (campuran) harta kekayaan dibatasi atau ditiadakan sama sekali, maka demi hukum akan ada persatuan (campuran) bulat antara harta kekayaan suami isteri, baik yang mereka bawa dalam perkawinan maupun yang mereka akan peroleh sepanjang perkawinan. ${ }^{23}$ Dalam hal terjadi persatuan bulat harta kekayaan perkawinan, maka dalam perkawinan tersebut pada prinsipnya hanya ada satu jenis harta kekayaan, yaitu harta bersama suami-isteri.

KUH Perdata mengatur pengecualian terhadap ketentuan tentang persatuan bulat harta kekayaan perkawinan, yaitu bilamana terdapat hubungan sangat pribadi antara harta dengan pemiliknya dan bilamana suami atau isteri menerima harta secara cuma-cuma, di mana si pewaris pemberi testamen maupun penghibah menyatakan dengan tegas, bahwa harta yang diwariskan atau dihibahkan menjadi milik pribadi suami atau Isteri yang menerimanya (Pasal 120 juncto Pasal 176 KUH Perdata). ${ }^{24}$

${ }^{23}$ Mochamad Soleh Alaidrus, 2009, "Pelaksanaan Pembagian Harta Perkawinan Dalam Perkawinan Poligami (Studi Di Pengadilan Agama Bekasi)," Tesis, Program Studi Magister Kenotariatan Program Pascasarjana Universitas Diponegoro, Semarang.

${ }^{24}$ Achmad Kardiansyah, 2008, "Harta Bersama Sebagai Objek Jaminan Hak Tanggungan ,Studi Di Pengadilan Negeri Tanjung Karang," Tesis, Program Pasca Sarjana, Program Studi Magister Kenotariatan, Universitas Diponegoro, Semarang.
Dalam hal demikian, maka walaupun suami istri tersebut melangsungkan perkawinan tanpa membuat perjanjian kawin, namun dalam perkawinan tersebut terdapat dua atau bahkan tiga macam harta kekayaan perkawinan, yaitu harta persatuan, harta pribadi suami dan/atau harta pribadi isteri. Jika dalam perkawinan baik suami maupun isteri masing-masing menerima secara cuma-cuma harta menurut Pasal 120 jo 176 KUHPerdata, maka dalam perkawinan itu terdapat tiga jenis harta yaitu harta persatuan, harta pribadi suami dan harta pribadi isteri. Namun jika hanya salah seorang dari suami isteri tersebut yang memperoleh harta secara cumacuma berdasar Pasal 120 jo Pasal 176 KUHPerdata, maka dalam perkawinan itu hanya terdapat dua macam harta, yaitu harta pribadi suami dengan harta persatuan atau harta pribadi isteri dengan harta persatuan.

Isteri tidak berhak lagi atas bagiannya dari aktiva harta gono-gini, kecuali hak atas pakaian, selimut dan sprei. Hal ini diatur dalam Pasal 132 ayat (1) KUH Perdata yang berbunyi sebagai berikut : "Isteri berhak melepaskan haknya atas harta bersama, segala perjanjian yang bertentangan dengan ketentuan ini batal, sekali melepaskan haknya, dia tidak boleh menuntut kembali apapun dari harta bersama, kecuali kain sprei dan pakaian pribadinya. Berdasarkan ketentuan ini hak isteri untuk melepaskan bagiannya tidak dihapuskan oleh perjanjian antara isteri dan suami atau antara isteri dengan pihak ketiga. Artinya, segala perjanjiannya yang bertentangan dengan ketentuan ini menjadi batal. $^{25}$

Batas waktu pelepasan hak diatur secara yuridis normative dalam Pasal 133 ayat (1) KUHPerdata. Pasal ini menyatakan bahwa isteri yang hendak mempergunakan hak tersebut dalam pasal yang lampau, wajib untuk menyampaikan akta pelepasan, dalam waktu satu bulan setelah pembubaran harta bersama itu, kepada panitera pengadilan negeri di tempat tinggal bersama yang terakhir, dengan ancaman kehilangan hak itu (jika lalai). Jika pelepasan hak itu terjadi karena meninggalnya suami, maka batas waktu sebulan itu dihitung sejak meninggalnya suami yang memang diketahui oleh isterinya. Hal ini diatur di dalam Pasal 133 ayat (2), yang menyatakan sebagai berikut: "Jika gabungan itu bubar akibat kematian suaminya, maka tenggang waktu satu bulan berlaku sejak isteri mengetahui kematian itu".

Sementara itu, harta benda dalam perkawinan dalam UU Perkawinan dikenal dengan istilah "harta bersama" atau harta gono gini. Kedudukan harta benda dalam perkawinan pengaturan harta tersebut diatur dalam: Pasal 35 jo Pasal 36 jo Pasal 37, ditambah dengan Pasal 65

${ }^{25}$ Happy Susanto, 2008, Pembagian harta gono-gini saat terjadi perceraiaan, Visimedia, Jakarta, hal. 30 . 
ayat (1) b dan c UU Perkawinan. Harta tersebut dirumuskan sebagai harta yang diperoleh selama perkawinan berlangsung. Hal ini diatur secara yuridis normatif dalam Pasal 35 ayat 1 UU Nomor 1 Tahun $1974 .^{26}$ Ini berarti terbentuknya harta bersama dalam perkawinan ialah sejak saat tanggal terjadinya perkawinan sampai ikatan perkawinan bubar. Harta yang diperoleh terhitung sejak saat berlangsungnya akad nikah, sampai saat perkawinan pecah baik oleh karena salah satu meninggal atau oleh karena perceraian, maka seluruh harta tersebut dengan sendirinya menurut hukum menjadi harta bersama. Penegasan seperti itu antara lain dapat dilihat dalam putusan Mahkamah Agung tanggal 5 Mei 1971 No. 803 $\mathrm{K} / \mathrm{SIP} / 1970 .{ }^{27}$ Dalam putusan ini dijelaskan harta yang dibeli oleh suami atau isteri di tempat yang jauh dari tempat tinggal mereka adalah termasuk harta bersama suami isteri jika pembelian dilakukan selama perkawinan.

Berdasarkan UUPA yang dapat mempunyai hak atas tanah dengan hak milik adalah warga negara Indonesia dan badan hukum tertentu. Orang asing yang memperoleh hak milik karena pewarisan tanpa wasiat dan/atau yang memperoleh hak milik karena percampuran harta dalam perkawinan, wajib melepaskan hak itu dalam jangka waktu 1 tahun sejak diperolehnya hak tersebut. Begitu pula WNI yang mempunyai hak milik kehilangan kewarganegaraannya, wajib melepaskan hak itu dalam jangka waktu 1 tahun setelah kehilangan kewarganegaraannya. Selanjutnya, orang yang mempunyai kewarganegaraan asing di samping kewarganegaraan Indonesianya memperoleh hak milik, maka wajib melepaskan hak itu dalam jangka waktu 1 tahun sejak diperolehnya hak tersebut.

UUPA mengatur bahwa yang berhak atas tanah dengan hak milik adalah warga negara Indonesia. Namun, faktanya WNI yang melakukan perkawinan campuran dengan WNA tanpa perjanjian perkawinan tidak berhak atas tanah dengan hak milik, dikarenakan terjadi percampuran harta dengan warga negara asing.

Akan tetapi, mengenai hak milik WNI yang didasarkan pada undang-undang tersebut di atas itu, dirasa sudah sangat perlu mengalami perubahan. Menurut Chairul Basri, hak kepemilikan atas tanah melekat pada subyek pemiliknya. Jika subyek adalah WNI, maka ia berhak atas status Hak Milik. Sedangkan, pasangan WNA-nya sebagai subjek orang asing

${ }^{26}$ Djaja S. Meliala, 2008, Himpunan Peraturan Perundang-undangan Tentang Perkawinan, cet. 1, Nuansa Aulia, Bandung, hal. 10.

${ }^{27}$ Muhammad Zainal Abidin, "Faktor-faktor Terjadinya Perceraian dan Terbentuknya Harta Bersama", (http://www.masbied.com/2011/03/30/faktorfaktor-terjadinya-perceraian danterbentuknyaharta-bersama), diakses tanggal 18 Agustus 2016. hanya berhak memiliki status hak pakai. ${ }^{28}$ Jadi, yang tidak berhak atas tanah dengan hak millik hanyalah warga negara asing baik karena pewarisan tanpa wasiat ataupun percampuran harta dalam perkawinan dan warga negara Indonesia yang kehilangan kewarganegaraannya.

Solusi terbaik saat ini yang juga merupakan dasar hukum yang kuat agar dapat digunakan untuk kepemilikan tanah dengan status hak milik, yakni penetapan pengadilan pisah harta. Penetapan pengadilan pisah harta adalah penetapan pengadilan tentang pemisahan harta bersama suami isteri setelah dikabulkannya permohonan pisah harta atau dikeluarkannya penetapan pengadilan ini. Yang tadinya dalam perkawinan campuran tersebut terjadi percampuran harta/harta bersama, setelah berlakunya penetapan ini menjadi terpisah. Apa yang dihasilkan oleh suami setelah penetapan ini adalah hanya menjadi milik suami dan begitu juga sebaliknya, apa yang dihasilkan isteri adalah hanya menjadi milik isteri seutuhnya. Namun, suami yang berkewarganegaraan asing sebagai kepala keluarga akan dan harus tetap bertanggung jawab sepenuhnya untuk biaya hidup keluarga dan juga pendidikan anak-anak yang telah dan akan dilahirkan oleh isterinya yang berkewarganegaraan Indonesia.

\section{Simpulan dan Saran}

\subsection{Kesimpulan}

1. Pengaturan hak pakai atas tanah bagi WNA yang melakukan perkawinan campuran, jika mereka menikah dengan perjanjian perkawinan maka WNA yang melaksanakan perkawinan dengan Orang Asing dapat memiliki hak atas tanah yang sama dengan WNI lainnya, hak atas tanah ini bukan merupakan harta bersama yang dibuktikan dengan perjanjian pemisahan harta antara suami dan istri, yang dibuat dengan akta notaris. Sebaliknya, apabila tidak memiliki perjanjian perkawinan maka harta yang dimiliki selama perkawinan menjadi harta bersama pasangan tersebut, pihak WNA ikut memiliki setengah dari harta tersebut.

2. Akibat hukum bila dalam perkawinan campuran telah memiliki

${ }^{28}$ Perca Indonesia, "Bedah Kasus Penetapan Pengadilan atas Pisah Harta Setelah Berlangsungnya Perkawinan bagi Pelaku Perkawinan Campuran di Indonesia : Tinjauan Hukum Terhadap Status Kepemilikan Properti”, Arikel diakses pada 18 Agustus 2016 dari http://percaindonesia.com/test2/. 
tanah atas nama warga negara Indonesia tanpa membuat perjanjian kawin sebelumnya, yang dalam hal ini tidak ada pemisahan harta, maka bagi WNI yang sudah memiliki tanah dengan status Hak Milik, dalam masa setahun perkawinannya harus melepaskan Hak Miliknya menjadi tanah negara dan kemudian mengajukan permohonan kembali untuk dijadikan Hak Pakai.

\subsection{Saran}

1. DPR bersama-sama dengan Pemerintah perlu membentuk undang-undang yang terkait dengan perkawinan campuran, agar tidak terjadi "conflict of law" (perselisihan hukum) dalam peraturan perundang-undangan terkait kepemilikan tanah bagi WNA yang berdomisili di Indonesia.

2. Agar Undang-Undang Nomor 1 Tahun 1974 tentang Perkawinan dan Undang-Undang Nomor 12 Tahun 2006 tentang Kewarganegaraan lebih ditaati, maka kepada masyarakat perlu diberikannya penyuluhan hukum tentang peranan dan akibat hukum dari perkawinan campuran terhadap status kewarganegaraan para pihak, sehingga akibat hukum yang timbul dari perkawinan campuran beralih kewarganegaraan terhadap status harta bersama.

\section{DAFTAR PUSTAKA}

Abidin, Muhammad Zainal, "Faktor-faktor Terjadinya Perceraian dan Terbentuknya Harta Bersama", (http://www.masbied.com/2011/03/30/faktor-faktor-terjadinyaperceraian danterbentuknya-harta-bersama), diakses tanggal 18 Agustus 2016.

Alaidrus, Mochamad Soleh, 2009, "Pelaksanaan Pembagian Harta Perkawinan Dalam Perkawinan Poligami (Studi Di Pengadilan Agama Bekasi)," Tesis, Program Studi Magister Kenotariatan Program Pascasarjana Universitas Diponegoro, Semarang.

Chomzah, H. Ali Achmad, 2002, Hukum Pertanahan; Pemberian Hak Atas Tanah Negara, Sertipikat dan Permasalahannya, Prestasi Pustaka, Jakarta.

Dijk, Van, 2006, Pengantar Hukum Adat Indonesia, diterjemahkan oleh A. Soehardi, Mandar Maju, Bandung.

Hutagalung, Arie S, , 2007, "Kemungkinan Pemilikan Satuan Rumah Susun oleh Orang- Orang Asing di Indonesia", Seminar Liberalisasi Hukum Tanah Indonesia, Balai Sidang Djokosoetono Fakultas Hukum Universitas Indonesia, Depok.

Ibrahim, Johny, 2012, Teori dan Metodologi Penelitian Hukum Normatif, Banyumedia, Malang.

Julius, Sembiring, 2004, Pengelolaan Tanah Kas Desa, Widya Bumi, Yogyakarta.

Kardiansyah, Achmad, 2008, "Harta Bersama Sebagai Objek Jaminan Hak Tanggungan ,Studi Di Pengadilan Negeri Tanjung Karang," Tesis, Program Pasca Sarjana, Program Studi Magister Kenotariatan, Universitas Diponegoro, Semarang.

Khairandy, Ridwan, 1999, Pengantar Hukum Perdata Internasional Indonesia, Gama Media, Yogyakarta.

Manan, Abdul, 2006, Aneka Masalah Hukum Perdata Islam di Indonesia, Kencana Prenada Media Group, Jakarta.

Marzuki, Peter Mahmud, 2011, Penelitian Hukum, Kencana Prenida Media, Jakarta.

Meliala, Djaja S., 2008, Himpunan Peraturan Perundang-undangan Tentang Perkawinan, cet. 1, Nuansa Aulia, Bandung.

Muchtar, Wahid, 2008, Memaknai Kepastian Hukum Hak Milik Atas Tanah, Republika, Jakarta.

Noor, Aslan, 2006, Konsepsi Hak Milik Atas Tanah Bagi Bangsa Indonesia, CV Mandar Maju, Bandung.

Perca Indonesia, "Bedah Kasus Penetapan Pengadilan atas Pisah Harta Setelah Berlangsungnya Perkawinan bagi Pelaku Perkawinan Campuran di Indonesia : Tinjauan Hukum Terhadap Status Kepemilikan Properti", Arikel diakses pada 18 Agustus 2016 dari http://percaindonesia.com/test2/. 
Ramelan, Eman, 2008, "Asas Pemisahan Horizontal dalam Hukum Tanah Nasional," Pidato Pengukuhan, Guru Besar Ilmu Hukum Agraria Universitas Airlangga.

Ramulyo, Mohd. Idris, 2006, Hukum Perkawinan, Hukum Kewarisan, Hukum Acara Peradilan Agama, dan zakat menurut hukum Islam, Sinar Grafika, Jakarta.

Simanjuntak, 2009, Pokok-Pokok Hukum Perdata Indonesia, Djambatan, Jakarta.

Soemitro, Ronny Hanitijo, 2008, Metode Penelitian Hukum dan Jurimetri, Alumni, Jakarta.

Subekti, 1995, Pokok-pokok Hukum Perdata, Cetakan XXVII, Internusa, Jakarta.

Sumardjono, Maria S.W., 2010, Kebijakan Pertanahan: Antara Regulasi dan Implementasi, Kompas, Jakarta.

Susanto, Happy, 2008, Pembagian harta gono-gini saat terjadi perceraiaan, Visimedia, Jakarta.

Syarifuddin, Amir, 2009, Hukum Perkawinan Islam di Indonesia, Kencana, Jakarta

$* * * * *$

Acta Comitas (2017) $1: 57-65$

ISSN : 2502-8960 I e-ISSN : 2502-7573

\title{
KUASA MENJUAL NOTARIIL SEBAgAi INSTRUMEN PEMENUHAN KEWAJIBAN DEBITUR YANG WANPRESTASI DALAM PERJANJIAN UTANG PIUTANG
}

Oleh :

\author{
Gede Dicka Prasminda* Yohanes Usfunan**, I Made Udiana*** \\ Mahasiswa Program Magister Kenotariatan Universitas Udayana \\ Email : dickaprasminda@gmail.com
}

\begin{abstract}
The granting of power of attorney to sell the land rights as an instrument for the fulfillment of the obligations of the debtor in a loan agreement of a notarial deed may commonly be found in the everyday practice of the notaries. Power of Attorney to sell is used by the proxy to sell the land of the authorizer in the event that the authorizer (debtor) experienced defaults. The Civil Law Code and the Law No. 4 of 1996 on Mortgage do not stipulate the power attorney to sell as an instrument in the loan agreement.

There are two legal contents analyzed from the vacancy of norms regarding the power of attorney to sell, namely: (1) how the arrangement of power of attorney to sell of the land rights as an instrument for the fulfillment of obligations on the loan agreement in the legislation on the guarantee law and (2) the legal effect of power of attorney to sell the land rights as an instrument for the fulfillment of obligations of the debtor in case of default under the loan agreements in connection with the execution of the law of guarantee. The type of research used in this thesis is a normative legal research with the statutory, concept and case approaches.

Based on the research results, it was revealed that the power of attorney to sell is based on the agreement of the parties which make the basis of the principle of freedom of contract. The Power of Attorney Deed shall be valid unless otherwise it is canceled by the judge with a court ruling that has the binding legal force. The use the deed of power of attorney to sell is considered weak because the power of attorney to sell can not be used as a basis for executing security object between the grantor and the recipient of the power of attorney.

Deed of power of attorney to sell is deemed not obtain legal certainty because at the time of registration of transfer of land rights, the power of attorney to sell can not be accepted by the local Land Registry Office. Responsibility for the grantor and the recipient of power of attorney is related to the obligations and rights of the grantor and the recipient of the power of attorney. As for the responsibility of the notary who made the deed of power of attorney to sell can be studied from three aspects, namely: (1). Civil responsibility; (2). Administrative responsibility; and (3). Criminal responsibility. Legal remedies that can be taken if the debtor is experiencing defaults can be done by way of a summons in advance without selling
\end{abstract}

